\title{
Does a Strong Safety Climate Protect Home Care and Hospice Nurses from Blood Exposure?
}

\author{
Jack Leiss \\ Cedar Grove Institute for Sustainable Communities, Mebane, NC, USA \\ Email: jackl@mcmoss.org
}

\begin{abstract}
In order to determine the association between safety climate and blood exposure in a population of home care/hospice nurses, a mail survey was conducted in 2006 in North Carolina, USA. Safety climate, defined as employees' shared perceptions regarding safety within their work organization, was examined according to level of use of safety-engineered medical devices and personal protective equipment (PPE), work experience, type of employment, and characteristics of the work environment. The adjusted response rate was $69 \%$. The overall exposure rate was 27.4 per 100,000 home visits. Nurses who had a weak safety climate had nearly $2 \frac{1}{2}$ times the risk of total blood exposure and twice the risk of needlestick as nurses who had a strong safety climate. Similar relationships were found for safety climate by use of safety devices and PPE, work experience, type of employment, and characteristics of the work environment. The author concluded that safety climate appears to be associated with reduced blood exposure among home care and hospice nurses. Safety climate may be among the factors that management can strengthen in order to reduce home care/hospice nurses' risk of blood exposure.
\end{abstract}

Keywords: Blood exposure, epidemiology, home care, needlestick and sharps injuries, nurse, safety climate, survey, risk

\section{Introduction}

Public health efforts in the United States to prevent bloodborne pathogen infection among home care and hospice nurses include mandated provision of personal protective equipment (PPE) and safetyengineered medical devices (safety devices) [1]. This issue is important because the potentially exposed population is already large and is expanding rapidly due to increasing employment in this sector [2], and is at risk of life-threatening infection from human immunodeficiency virus (HIV), hepatitis B virus (HBV), and hepatitis C virus (HCV) [3]. Although some home care/hospice agencies do not always provide their nurses with the necessary PPE and safety devices, even when these items are available they are not always used $[4,5]$. Although employers are generally required to ensure employees' use of PPE and safety devices when appropriate, because the home care environment is not under the control of the employer or any public health agency, this requirement is waived for care given in the patient's home [6].

Safety climate has been associated with PPE use in a number of settings [7, 8]. Moreover, a strong safety climate has been shown to be associated with PPE use among home care and hospice nurses [9]. However, it is not known whether safety climate, which is defined as employees' shared perceptions regarding safety within their work organization [10], is associated with reduced blood exposure in this population. If it is, providing a strong safety climate may be a powerful and cost-effective way for home care/hospice agencies to reduce blood exposure among their nurses. Therefore, the objective of the present study was to examine the association between safety climate and blood exposure in a population of home care and hospice nurses. This study builds on previous work by examining safety climate and blood exposure in the context of other factors that have been found to be associated with reduced exposure, including use of PPE and safety devices, work experience, type of employment, and characteristics of the work environment [11-14]. 


\section{Subjects and Methods}

The North Carolina Study of Home Care and Hospice Nurses was a mail survey conducted in 2006 of registered nurses listed in the licensing database of the North Carolina Board of Nursing as working in home care or hospice in non-administrative positions. The questionnaire is included in the online supplemental material to this paper. SAS 9.2 (SAS Institute, Cary, NC) was used to calculate percentages, rates, ratios, and confidence intervals. Complete details of the study design have been published previously [11]. This study was approved by the Institutional Review Board of Weber State University.

\subsection{Safety Climate}

Items that are applicable to home-care nursing (as opposed to hospital-based nursing) were selected from Gershon et al.'s [15] safety climate scale. The eight items cover a broad range of subcategories and include support for safety programs, senior management support for safety, communication and feedback about safety, and training and education. The eight items were "The protection of workers from occupational blood exposures is a high priority with management," "Reporting blood exposures helps management protect nurses from future blood exposures," "Employees, supervisors, and managers all work together to ensure the safest possible working conditions," "Employees are encouraged by management to make suggestions for improving worker safety," "My supervisor often discusses safe work practices with me," "When a new device is introduced, there are procedures in place to ensure I've been correctly trained to use the new device," "Supervisors correct unsafe work practices," and "Employees are taught to be aware of and to recognize potential health hazards at work." Response options were numbered 1 (labeled "strongly disagree") to 5 (labeled "strongly agree"). These eight items were highly correlated (Cronbach alpha $=0.94$ ) and were combined into a dichotomous composite measure (equivalent to a median split) indicating a strong (combined score $>3$ ) or weak $(\leqslant 3)$ safety climate.

\subsection{Blood Exposure}

Possible routes of blood exposure (needlestick; exposure to the eyes, nose, and mouth; and blood on nonintact skin) were identified in preliminary research [16]. As a result, for the present survey, several questionnaire items asked about these types of blood exposure incidents during the previous 12 months. Nurses were considered to have had a blood exposure if they indicated that, during this time period, they had been stuck by a needle or lancet after it had been used on a patient; had gotten patient's blood or body fluid containing visible blood in their eyes, nose, or mouth; or had gotten patient's blood or body fluid containing visible blood on non-intact skin. For the present analysis, the number of such incidents was counted.

\subsection{Use of Safety Devices}

Use of safety devices was measured by six questions that referred to the last time the nurse used a particular type of device and asked whether it had the appropriate safety feature. For example, "The last time you used an IV catheter, did it have a shielded or blunted stylet?" The six types of devices asked about were winged steel needle (was it shielded?), lancet (retracting/shielded?), syringe (sliding shield, hinged cap, or retracting needle?), IV catheter, straight needle (hinged cap/shield?), and blood tube holder (hinged cap?). Response options were yes and no. Additional analyses of these data were presented previously [4].

\subsection{Use of PPE}

Use of PPE was measured by posing patient care scenarios in which use of the equipment was indicated to prevent blood exposure. In response to the scenarios, nurses could indicate that they always used the equipment when performing that procedure, or they could select from several reasons for not using the equipment. One of the scenarios was relevant for this study: whether, the last time the nurse provided ostomy care, a fluid-impermeable apron was worn. This equipment is intended to prevent exposure from 
blood getting on non-intact skin [17]. Scenarios involving PPE designed to prevent blood exposure to the eyes, nose, and mouth are not shown because of the small number of exposures by this route. Additional analyses of these data were presented previously [5].

\subsection{Work Experience, Type of Employment, and Characteristics of the Work Environment}

Work experience was calculated from dates reported by the respondent. Type of employment (full time or part time/contract) was also self-reported. Two types of characteristics of the work environment were examined. One was whether the nurse reported agreeing with the statement, "I always have enough time during a home visit so that I don't have to rush." Responses were indicated on a five point scale ranging from strongly disagree to strongly agree. Nurses were categorized as not having to rush (responses of 4 or 5) or having to rush (responses of 1, 2, or 3). Additional analyses of these data were presented previously [18].

Secondly, characteristics of homes visited were measured by four items asking how often the nurse visited homes with unrestrained pets; unsupervised, unruly children; poor lighting; and "cluttered homes where I have to clear a space around the patient to place my medical supplies," (i.e., adverse conditions). Response options were never, sometimes, usually, and always. Nurses were categorized as usually/always (or often) or sometimes/never (not often) visiting homes with at least one of these characteristics. A detailed analysis of these data was presented previously [18].

\section{$3 \quad$ Results}

Questionnaires were received from 833 eligible nurses, whereas 640 nurses did not return the questionnaire or refused to participate in the study. Based on the assumption that the proportion of eligible nurses from among those who did not return the questionnaire or could not be contacted was similar to the proportion among those who did return the questionnaire, the adjusted response rate was $69 \%$. Participants were primarily white (91\%), female (96\%), and between the ages of 36 and 55 years $(63 \%)$

Eighty-five percent of nurses reported a strong safety climate. Nine percent of nurses reported one or more blood exposures during the past year. The overall incidence rate was 27.4 (95\% confidence interval (CI): 20.2, 34.6) exposures per 100,000 home visits.

The percentage of nurses who reported using the specified safety device the last time they used that type of device was $85 \%$ (winged steel needle), 76\% (lancet), $82 \%$ (syringe), $85 \%$ (IV catheter), $70 \%$ (straight needle), and $57 \%$ (blood tube holder). The percentage who reported always wearing a fluidimpermeable apron when providing ostomy care was 20\%. Sixty-one percent of nurses had six or more years of experience working in home care/hospice; $77 \%$ worked in their jobs on a full-time basis. Fiftyfive percent of nurses agreed that they do not have to rush during a visit; $63 \%$ often visited homes with at least one of the specified adverse conditions.

Nurses who worked in an environment with a weak safety climate had nearly two and a half times the risk of total blood exposure as nurses who worked in an environment with a strong safety climate (risk ratio, 2.4 (95\% CI: 1.6, 3.2)). They had twice the risk of needlestick (Table 1). Furthermore, both nurses who did and did not use the specified safety device had lower risk of exposure if they worked in an organization that had a strong safety climate. Ratios between the weak and strong safety climate groups could not be calculated for all of the devices because of small n's. Nevertheless, for all devices, the rate of exposure was greater in the weak safety climate group than in the strong safety climate group. (Rates of exposure could not be calculated for two types of devices (winged steel needle and blood tube holder) for one of the safety device categories because the number of exposures was 0.) 
Table 1. Blood exposure rates (per 100,000 home visits) from needlestick among home care and hospice nurses, by type of medical device, whether it was safety-engineered (the last time the nurse used that type of device), and safety climate, North Carolina, $2006(\mathrm{~N}=833)$

\begin{tabular}{|c|c|c|c|c|c|c|c|}
\hline \multirow{2}{*}{ Type of Device } & \multirow{2}{*}{$\begin{array}{c}\text { Was safety } \\
\text { device? }\end{array}$} & \multirow{2}{*}{ Safety Climate } & \multirow[b]{2}{*}{$\mathrm{n}$} & \multirow[b]{2}{*}{ Rate } & \multirow[b]{2}{*}{$95 \% \mathrm{CI}$} & \multicolumn{2}{|c|}{ Rate ratio $^{\mathrm{b}}$} \\
\hline & & & & & & Ratio & $95 \% \mathrm{CI}$ \\
\hline \multirow{2}{*}{ Total $^{\mathrm{a}}$} & & Weak & 20 & 24 & $(9.8,39)$ & & \\
\hline & & Strong & 47 & 12 & $(7.7,17)$ & 2.0 & $(1.2,2.8)$ \\
\hline \multirow{4}{*}{$\begin{array}{l}\text { Winged steel } \\
\text { needle }\end{array}$} & \multirow{2}{*}{ No } & Weak & 0 & & & & \\
\hline & & Strong & 5 & 5.7 & $(0,13)$ & & \\
\hline & \multirow{2}{*}{ Yes } & Weak & 5 & 12 & $(0,26)$ & & \\
\hline & & Strong & 16 & 3.1 & $(1.3,4.8)$ & 3.9 & $(1.6,6.2)$ \\
\hline \multirow{4}{*}{ Lancet } & \multirow{2}{*}{ No } & Weak & 4 & 17 & $(0,38)$ & & \\
\hline & & Strong & 9 & 7.4 & $(1.3,14)$ & & \\
\hline & \multirow{2}{*}{ Yes } & Weak & 2 & 3.8 & $(0,10)$ & & \\
\hline & & Strong & 10 & 1.6 & $(0.2,3.0)$ & & \\
\hline \multirow{4}{*}{ Syringe } & \multirow{2}{*}{ No } & Weak & 3 & 17 & $(0,44)$ & & \\
\hline & & Strong & 3 & 2.3 & $(0,6.2)$ & & \\
\hline & \multirow{2}{*}{ Yes } & Weak & 3 & 5.1 & $(0,11)$ & & \\
\hline & & Strong & 18 & 3.7 & $(1.7,5.7)$ & & \\
\hline \multirow{4}{*}{ IV catheter } & \multirow{2}{*}{ No } & Weak & 3 & 18 & $(0,44)$ & & \\
\hline & & Strong & 7 & 3.7 & $(0,8.1)$ & & \\
\hline & \multirow{2}{*}{ Yes } & Weak & 3 & 5.3 & $(0,12)$ & & \\
\hline & & Strong & 11 & 1.9 & $(0.3,3.4)$ & & \\
\hline \multirow{4}{*}{ Straight needle } & \multirow{2}{*}{ No } & Weak & 4 & 12 & $(0,29)$ & & \\
\hline & & Strong & 8 & 3.6 & $(0,7.4)$ & & \\
\hline & \multirow{2}{*}{ Yes } & Weak & 2 & 6.8 & $(0,17)$ & & \\
\hline & & strong & 13 & 3.6 & $(1.5,5.7)$ & 1.9 & $(0.8,3.0)$ \\
\hline \multirow{4}{*}{ Blood tube holder } & \multirow{2}{*}{ No } & Weak & 6 & 14 & $(0,28)$ & & \\
\hline & & Strong & 7 & 2.7 & $(0.1,5.3)$ & 5.1 & $(0.2,10)$ \\
\hline & \multirow{2}{*}{ Yes } & Weak & 0 & & & & \\
\hline & & Strong & 10 & 2.1 & $(0.2,4.0)$ & & \\
\hline
\end{tabular}

$n$, number of blood exposures; $C I$, confidence interval. ${ }^{\mathrm{a}}$ All nurses. ${ }^{\mathrm{b}}$ Comparing weak to strong safety climate within strata. Some ratios were not calculated because of small n's.

Similar relationships were found between safety climate and blood exposure among nurses who did and did not always wear a fluid-impermeable apron when providing ostomy care (Table 2).

Table 2. Blood exposure rates (per 100,000 home visits) from getting blood on non-intact skin among home care and hospice nurses, by use of PPE and safety climate, North Carolina, 2006 (N=833)

\begin{tabular}{|c|c|c|c|c|c|c|c|}
\hline \multirow[b]{2}{*}{ Scenario } & \multirow[b]{2}{*}{ Use of PPE } & \multirow{2}{*}{$\begin{array}{l}\text { Safety } \\
\text { Climate }\end{array}$} & \multirow[b]{2}{*}{$\mathrm{n}$} & \multirow[b]{2}{*}{ Rate } & \multirow[b]{2}{*}{$95 \%$ CI } & \multicolumn{2}{|c|}{ Rate ratio ${ }^{a}$} \\
\hline & & & & & & Ratio & $95 \% \mathrm{CI}$ \\
\hline \multirow{4}{*}{$\begin{array}{l}\text { When providing ostomy care, uses } \\
\text { fluid-impermeable apron... }\end{array}$} & \multirow{2}{*}{ Not always } & Weak & 20 & 30 & $(14,48)$ & & \\
\hline & & Strong & 43 & 18 & $(12,25)$ & 1.7 & $(1.1,2.4)$ \\
\hline & \multirow{2}{*}{ Always } & Weak & 0 & & & & \\
\hline & & Strong & 4 & 2.5 & $(0,7.2)$ & & \\
\hline
\end{tabular}

PPE, personal protective equipment; $n$, number of blood exposures; CI, confidence interval. ${ }^{\text {a Comparing weak to }}$ strong safety climate within strata. The ratio for nurses who always used the requisite PPE for that procedure was not calculated because of small n's. 
Furthermore, a strong safety climate was associated with lower blood exposure among nurses who did and did not have six or more years of home care/hospice experience, worked full time (but not part time/contract), did and did not have to rush during home visits, and did and did not often work in homes with adverse conditions (Table 3).

Table 3. Blood exposure rates (per 100,000 home visits) among home care and hospice nurses, by four factors previously found to be associated with risk of blood exposure or use of PPE/safety medical devices, safety climate, and route of exposure, North Carolina, $2006(\mathrm{~N}=833)$

\begin{tabular}{|c|c|c|c|c|c|c|c|c|c|c|c|c|c|c|c|}
\hline \multirow[b]{3}{*}{ Factor } & \multirow{3}{*}{$\begin{array}{l}\text { Level of } \\
\text { Factor }\end{array}$} & \multirow{3}{*}{$\begin{array}{c}\text { Safety } \\
\text { Climate } \\
\end{array}$} & \multicolumn{5}{|c|}{ Total $^{\mathrm{a}}$} & \multicolumn{3}{|c|}{ Needlestick $^{\mathrm{b}}$} & \multicolumn{5}{|c|}{ Blood on non-intact skin } \\
\hline & & & \multirow[b]{2}{*}{$\mathrm{n}$} & \multirow[b]{2}{*}{ Rate } & \multirow[b]{2}{*}{$95 \%$ CI } & \multicolumn{2}{|c|}{ Rate ratio $^{c}$} & \multirow[b]{2}{*}{$\mathrm{n}$} & \multirow[b]{2}{*}{ Rate } & \multirow[b]{2}{*}{$95 \%$ CI } & \multirow[b]{2}{*}{$\mathrm{n}$} & \multirow[b]{2}{*}{ Rate } & \multirow[b]{2}{*}{$95 \% \mathrm{CI}$} & \multicolumn{2}{|c|}{ Rate ratio $^{c}$} \\
\hline & & & & & & Ratio & $95 \% \mathrm{CI}$ & & & & & & & Ratio & $95 \% \mathrm{CI}$ \\
\hline \multirow{4}{*}{$\begin{array}{l}\text { Years of } \\
\text { experience in } \\
\text { home } \\
\text { care/hospice } \\
\text { nursing }\end{array}$} & \multirow{2}{*}{$\leqslant 5$} & Weak & 31 & 82 & $(13,152)$ & & & 4 & & & 11 & 34 & $(3.6,64)$ & & \\
\hline & & Strong & 36 & 31 & $(20,42)$ & 2.6 & $(1.7,3.6)$ & 11 & 5.9 & $(2.0,9.7)$ & 22 & 23 & $(13,34)$ & 1.5 & $(0.8,2.2)$ \\
\hline & \multirow[t]{2}{*}{$6+$} & Weak & 14 & 25 & $(10,39)$ & & & 2 & & & 9 & 18 & $(4.9,31)$ & & \\
\hline & & Strong & 42 & 13 & $(4.4,21)$ & 1.9 & $(0.7,3.2)$ & 10 & 1.7 & $(0.1,3.3)$ & 25 & 5.1 & $(1.7,8.5)$ & 3.5 & $(1.2,5.8)$ \\
\hline \multirow{4}{*}{$\begin{array}{l}\text { Type of } \\
\text { employment }\end{array}$} & \multirow[t]{2}{*}{$\mathrm{PT}$} & Weak & 8 & 30 & $(2.9,58)$ & & & 2 & & & 5 & 19 & $(0,43)$ & & \\
\hline & & Strong & 12 & 27 & $(13,40)$ & 1.1 & $(0.6,1.7)$ & 4 & & & 7 & 20 & $(8.2,31)$ & 1.0 & $(0.4,1.5)$ \\
\hline & \multirow[t]{2}{*}{$\mathrm{FT}$} & Weak & 37 & 53 & $(15,91)$ & & & 4 & & & 15 & 26 & $(8.6,44)$ & & \\
\hline & & Strong & 66 & 18 & $(10,26)$ & 2.9 & $(1.7,4.2)$ & 17 & 2.5 & $(1.0,4.1)$ & 40 & 10 & $(5.0,15)$ & 2.6 & $(1.3,3.9)$ \\
\hline \multirow{4}{*}{$\begin{array}{l}\text { Has to rush } \\
\text { on home visit }\end{array}$} & \multirow[t]{2}{*}{ Yes } & Weak & 36 & 52 & $(12,92)$ & & & 4 & & & 15 & 23 & $(5.9,41)$ & & \\
\hline & & Strong & 49 & 18 & $(9.3,28)$ & 2.9 & $(1.4,4.3)$ & 10 & 2.7 & $(0.4,5.0)$ & 33 & 13 & $(4.5,22)$ & 1.8 & $(0.6,2.9)$ \\
\hline & \multirow[t]{2}{*}{ No } & Weak & 9 & 39 & $(8.0,69)$ & & & 2 & & & 5 & 27 & $(0,54)$ & & \\
\hline & & Strong & 27 & 16 & $(10,22)$ & 2.4 & $(1.6,3.3)$ & 11 & 3.9 & $(1.3,6.4)$ & 14 & 12 & $(6.7,17)$ & 2.3 & $(1.3,3.2)$ \\
\hline \multirow{4}{*}{$\begin{array}{l}\text { Adverse } \\
\text { conditions in } \\
\text { homes visited }\end{array}$} & \multirow[t]{2}{*}{$\mathrm{U} / \mathrm{A}$} & Weak & 35 & 49 & $(10,87)$ & & & 4 & & & 15 & 23 & $(5.7,40)$ & & \\
\hline & & Strong & 59 & 23 & $(13,33)$ & 2.1 & $(1.2,3.0)$ & 14 & 4.2 & $(1.8,6.6)$ & 37 & 13 & $(6.2,19)$ & 1.8 & $(0.9,2.7)$ \\
\hline & \multirow[t]{2}{*}{$\mathrm{S} / \mathrm{N}$} & Weak & 10 & 46 & $(12,80)$ & & & 2 & & & 5 & 29 & $(1.0,57)$ & & \\
\hline & & Strong & 19 & 15 & $(7.9,21)$ & 3.1 & $(1.7,4.5)$ & 7 & 2.0 & $(0,4.4)$ & 10 & 12 & $(5.7,18)$ & 2.4 & $(1.2,3.6)$ \\
\hline
\end{tabular}

PPE, personal protective equipment; n, number of blood exposures; CI, confidence interval; PT, part time or contract; FT, full time; U/A, usually or always, i.e., often; S/N, sometimes or never, i.e., seldom. ${ }^{\text {ancludes blood }}$ exposure to the eyes, nose, and mouth. This route is not shown separately because of its small number of exposures. ${ }^{b}$ Ratios and some rates were not calculated because of small $n$ 's. 'Comparing weak to strong safety climate within strata.

\section{Discussion}

Safety climate appears to be associated with reduced blood exposure among home care and hospice nurses. This study found that the association holds for nurses who did and did not use a safetyengineered medical device the last time they used that particular type of device, do and do not always use the selected item of PPE when it is indicated, had fewer or greater years of experience in home care/hospice, worked full time, did and did not have to rush during home visits, and seldom or often visited homes with adverse conditions. The findings for these subgroups are important because these factors are prevalent in home care/hospice [18] and several have been associated with blood exposure [11, 12]. If the association between safety climate and blood exposure proves to be causal, these findings will indicate that, while improving the above factors is important for reducing nurses' blood exposure [11], such improvement will need to be accompanied by a strong safety climate in order to further reduce their exposure.

The finding that a strong safety climate is associated with reduced blood exposure is consistent with the results of other studies, which have found reduced blood exposure associated with a strong safety climate among other populations of home care/hospice [10] and hospital-based nurses [19, 20] as well as reduced injury or accident rates among workers in a variety of industries [21, 22]. One difficulty in 
drawing firm conclusions from this diverse literature is the different ways in which safety climate has been operationalized. Future research should develop measures of safety climate that can be used across many different types of work environments [23].

Future research should also elucidate steps that management can take to produce a strong safety climate [24-26]. Some factors that have been proposed as important include leadership [27] and organizational justice [28].

The direction of causality in the association between safety climate and blood exposure cannot be determined from the present study. Furthermore, many of the rates and ratios were estimated with low precision (i.e., wide confidence intervals) due to the small number of exposures in the relevant groups, especially for needlestick exposures. Kim et al. [29] have shown the validity of using "near-misses" to increase the number of exposures available for study. In order to strengthen the conclusions drawn from future studies, research should investigate the direction of causality in the association between safety climate and blood exposure using sufficient number of exposures.

Acknowledgments. This survey upon which this study is based was funded by Grant OH008241 from the Centers for Disease Control and Prevention/National Institute for Occupational Safety and Health. The findings and conclusions in this report are those of the author and do not necessarily represent the views of the National Institute for Occupational Safety and Health. The author thanks Linda Lacey of the North Carolina Center for Nursing for help with the Board of Nursing data; Kathy Culliton, MS, APRN and Cynthia Gecik, MSN, RN for help in understanding the PPE data; and members of the study team: Cynthia Klein, PhD, Jennifer T. Lyden, MPH, Rahel Mathews, MPH, Kathleen L. Sitzman, RN, PhD, Abenah Vanderpuije, MPH, and Mary Agnes Kendra, RN, PhD.

\section{References}

1. Occupational Safety and Health Administration. Bloodborne Pathogens Standard (29 CFR 1910.1030) 2007. http://www.osha.gov/pls/oshaweb/owadisp.show_document?p_table=STANDARDS\&p_id=10051. Accessed February 26, 2014.

2. Bureau of Labor Statistics. Occupational employment statistics. May 2013 national industry-specific occupational employment and wage estimates. NAICS 621600 - home health care services 2014. http://www.bls.gov/ oes/current/naics4_621600.htm\#b00-0000. Accessed December 18, 2014.

3. World Health Organization (2002) The world health report 2002: reducing the risks, promoting healthy life, Geneva, WHO.

4. Leiss JK (2010) Provision and use of safety-engineered medical devices among home care and hospice nurses in North Carolina, Am J Infect Control 38, 636-639.

5. Leiss JK, Sitzman KL, Kendra MA (2011) Provision and use of personal protective equipment among home care and hospice nurses in North Carolina, Am J Infect Control 39, 123-128.

6. Occupational Safety and Health Administration. The BBP standard applicability to home health care service workers. Standard Interpretations 05/04/2000 2000. http://www.osha.gov/pls/oshaweb/ owadisp.show_document?p_table=INTERPRETATIONS\&p_id=23454. Accessed April 19, 2009.

7. Gershon RR, Vlahov D, Felknor SA, Vesley D, Johnson PC, Delclos GL, Murphy LR (1995) Compliance with universal precautions among health care workers at three regional hospitals, Am J Infect Control 23, 225-236.

8. Rivers DL, Aday LA, Frankowski RF, Felknor S, White D, Nichols B (2003) Predictors of nurses' acceptance of an intravenous catheter safety device, Nurs Res 52, 249-255.

9. Leiss JK (2014) Safety climate and use of personal protective equipment and safety medical devices among home care and hospice nurses, Ind Health 52, 492-497.

10.Gershon RRM, DeJoy DM, Borwegen B, Braun B, Silverstein B, Stock L, Cullen J, Braun B (2009) Health and safety culture. In: State of the sector: Healthcare and social assistance (DHHS (NIOSH) Publication No. 2009139), CDC/NIOSH, 87-97.

11.Leiss JK, Lyden JT, Mathews R, Sitzman KL, Vanderpuije A, Mav D, Kendra MA, Klein C, Humphrey CJ (2009) Blood exposure incidence rates from the North Carolina Study of Home Care and Hospice Nurses, Am J Ind Med 52, 99-104. 
12.Leiss JK (2012) Work experience, work environment, and blood exposure among home care and hospice nurses, Ind Health 50, 521-528.

13.Tuma S, Sepkowitz KA (2006) Efficacy of safety-engineered device implementation in the prevention of percutaneous injuries: a review of published studies, Clin Infect Dis 42, 1159-1170.

14.Gammon J, Morgan-Samuel H, Gould D (2008) A review of the evidence for suboptimal compliance of healthcare practitioners to standard/universal infection control precautions, J Clin Nurs 17, 157-167.

15.Gershon RR, Karkashian CD, Grosch JW, Murphy LR, Escamilla-Cejudo A, Flanagan PA, Bernacki E, Kasting C, Martin L (2000) Hospital safety climate and its relationship with safe work practices and workplace exposure incidents, Am J Infect Control 28, 211-221.

16.Leiss JK, Lyden JT, Klein C (2011) Using formative research to design an epidemiologic survey: The North Carolina Study of Home Care and Hospice Nurses, Epidemiol Health 33, e2011008.

17. Occupational Safety and Health Administration. Enforcement procedures for the occupational exposure to bloodborne pathogens. Directive no. CPL 02-02-069 2009. http://www.osha.gov/pls/oshaweb/ owadisp.show_document?p_table=DIRECTIVES\&p_id=2570\#XI. Accessed May 31, 2009.

18.Sitzman KL, Leiss JK (2009) Documentation of incidental factors affecting the home healthcare work environment, Home Healthc Nurse 27, 516-521.

19.Stone PW, Gershon RR (2006) Nurse work environments and occupational safety in intensive care units, Policy Polit Nurs Pract 7, 240-247.

20.Taylor JA, Dominici F, Agnew J, Gerwin D, Morlock L, Miller MR (2012) Do nurse and patient injuries share common antecedents? An analysis of associations with safety climate and working conditions, BMJ Qual Saf 21, 101-111.

21.Arcury TA, Summers P, Rushing J, Grzywacz JG, Mora DC, Quandt SA, Lang W, Mills TH (2014) Work safety climate, personal protection use, and injuries among Latino residential roofers, Am J Ind Med.

22.Varonen U, Mattila M (2000) The safety climate and its relationship to safety practices, safety of the work environment and occupational accidents in eight wood-processing companies, Accid Anal Prev 32, 761-769.

23.Lee J, Huang Y-h, Robertson MM, Murphy LA, Garabet A, Chang W-R (2014) External validity of a generic safety climate scale for lone workers across different industries and companies, Accid Anal Prev 63, 138-145.

24.Stokols D, McMahan S, Clitheroe Jr H, Wells M (2001) Enhancing corporate compliance with worksite safety and health legislation, J Safety Res 32, 441-463.

25.Vredenburgh AG (2002) Organizational safety: which management practices are most effective in reducing employee injury rates? J Safety Res 33, 259-276.

26.Zohar D (2000) A group-level model of safety climate: testing the effect of group climate on microaccidents in manufacturing jobs, J Appl Psychol 85, 587-596.

27.Zohar D, Huang Y-h, Lee J, Robertson M (2014) A mediation model linking dispatcher leadership and work ownership with safety climate as predictors of truck driver safety performance, Accid Anal Prev 62, 17-25.

28.Gyekye SA, Haybatollahi M (2014) Relationship between organizational justice and organizational safety climate: do fairness perceptions influence employee safety behaviour?, Int J Occup Saf Ergon 20, 199-211.

29.Kim H, Kriebel D, Quinn MM, Davis L (2010) The snowman: A model of injuries and near-misses for the prevention of sharps injuries, Am J Ind Med 53, 1119-1. 